\title{
Problematyka odpowiedzialności perlokucyjnej w pracy nauczycielskiej
}

\section{Perlocutive responsibility in educational process at school}

\author{
Bożena Niećko-Bukowska \\ Institute of Linguistics, Adam Mickiewicz University \\ al. Niepodległości 4, 61 - 847 Poznań \\ bniecko@amu.edu.pl
}

\begin{abstract}
This article is about the relation between axiology and linguistics. This axiolinguistics study focuses on the issue of responsibility for the speech acts. The perlocutive responsiblility is the responsiblility for social facts created by means of acts of speech. The responsiblility is related to the teaching and education in social practice. I have described the development of the notion of responsibility starting from the Roman law up to Heidegger's ontologisation of the responsibility. I refer to the problem of evaluation of reality by humans, by means of assessments, performatives and norms; to the responsibility for the transmission of values among generations. The idea of perlocutive responsibility is shown on the example of education processes at school.
\end{abstract}

\section{Wstęp}

Aksjologiczna refleksja nad zagadnieniem celów i metod edukacji jest bliska każdemu, komu zależy na kształceniu nieobojętnym wobec otaczającej człowieka rzeczywistości. Niejednokrotnie można usłyszeć, że edukacja pozbawiona kierunkowskazu uświadomionych wartości przypominałaby tresurę bezmyślnych „robotów społecznych”. Odpowiedzialność, samorealizacja $\mathrm{i}$ tolerancja to zarówno podstawowe kategorie pojęciowe jak i postulowane preferencje współczesnego nauczania i wychowywania. W edukacji ukierunkowanej na owe wartości można upatrywać nadziei na kształtowanie postawy odpowiedzialności obywatelskiej. Zanim uczeń zacznie kierować się w swoim życiu poczuciem odpowiedzialności, najpierw kreatywnie odkrywa to, co jest dla niego wartościowe. W poszukiwaniach tych waerości pomocą powinien służyć nauczyciel. W procesie edukacji szkolnej wartości, przekładalne na system norm postępowania, wyznaczają cele kształcenia i pozostają źródłem inspiracji dydaktyczno-wychowawczych.

\section{Charakterystyka odpowiedzialności nauczycielskiej}

Należy na wstępie przybliżyć genezę pojęcia „odpowiedzialności”. Pojęcie „odpowiedzialności” wywodzi się z języka prawniczego. Używane w prawie rzymskim terminy: respondere, responsio, responsum, artykułowały swoje odpowiedniki w językach europejskich. „Odpowiadanie” oznaczało: odpowiadać przed sądem na oskarżenie, bronić kogoś przed sądem, usprawiedliwiać 
swoje czyny. Za sprawą religii chrześcijańskiej sądowy model odpowiedzialności ${ }^{1}$ osiagnął wymiar eschatologiczny a „odpowiedzialność” z pojęcia prawniczego przekształcono w pojęcie etyczne oraz wprowadzono termin imputatio. Dzięki klasycznej filozofii niemieckiej oraz poglądom I. Kanta pojawiła się w filozofii idea odpowiedzialności za wybór uogólnionej maksymy postępowania, odpowiedzialności przed prawem moralnym. Poszerzeniu horyzontów odpowiedzialności sprzyjały narodziny egzystencjalizmu. Człowiek stał się odpowiedzialnym za swoje czyny niezależnie od tego, czy zostaje za nie pociągnięty do odpowiedzialności przez sąd, czy odpowiedzialność zostaje mu przypisana przez społeczność. Do zontologizowania odpowiedzialności przyczyniła się filozofia M. Heideggera, znosząc odróżnienie etyki od ontologii. Odpowiedzialność stała się ontologicznym efektem bieżącej obecności (Dasein, Filek 1996: 7, 18-19).

Dla odpowiedzialności rozumianej w sensie nabywanej kwalifikacji ocennej charakterystyczne będzie operowanie orzecznikami ocenotwórczymi - denotującymi cechy, za które zwykło się w danym uniwersum spłecznym chwalić bądź ganić. Zakres tak rozumianej odpowiedzialności dotyczy zarówno czynów zakazanych jak i nakazanych i z uwagi na rodzaj czynu orzeka się zachodzenie bądź brak odpowowiedzialności. Natomiast w przypadku ontologicznie rozumianej odpowiedzialności orzecznik „odpowiedzialny” posiada charakter opisowy, denotujący ontologicznie niezbywalny stan bycia odpowiedzialnym, który może stać się podstawą do wyrażenia konkretnej oceny. W duchu tak rozumianej odpowiedzialności, zakres odpowiedzialności obejmuje całościowy wymiar ludzkiego bycia. Działania oceniane społecznie jako nieodpowiedzialne pozostaja $\mathrm{w}$ aksjo-ontologicznej strukturze bycia odpowiedzialnym, natomiast działania nie-odpowiedzialnościowe - o ile takowe w ogóle zachodzą - nie konstytuowałyby specyficznie ludzkiego bytu, gdyż znajdują się one poza ontologiczną strukturą odpowiedziaolności.

Odpowiedzialność odkrywana jest przez podmiot - jako normatywny efekt egzystencji uobecniony w kreacyjnie używanym języku - a poprzez doświadczenie powinności. W sądowym modelu odpowiedzialności podmiot był pociagany do odpowiedzialności za jakieś wobec kogoś działanie, za to co zrobił, a nie za to kim jest. Natomiast w modelu ontologicznym odpowiedzialność podmiotu ukonstytuowana jest w jego własnym byciu będącym - jako takim działaniem (w tym zaniechaniem). Jest to odpowiedzialność za to jak się jest (egzystuje). I tak, podmiot odpowiedzialny jest za działania mową, którą stwarza rzeczywistość społeczna, np. steruje ludzkimi przekonaniami i postępowaniem. Akty mowy stają się przedmiotem odpowiedzialności. W rezultacie podmiot zawsze pozostaje odpowiedzialny, nawet gdy działa nieodpowiedzialnie (np. niedbale). Skoro indywidualna egzystencja jest faktem normatywnym (inaczej: wartościa), czyli powinnościowym, od odpowiedzialności wpisanej w ontologiczną strukturę bytu ludzkiego cechującego się rozumnością, świadomością i wolnością działania - nie można uciec.

Za pomocą języka proponowany bywa ludziom obraz świata. Za pomocą języka rodzice i nauczyciele przekazują własny obraz świata (Lebenswelt) dzieciom. Językowy obraz świata rozumiany jest najogólniej jako interpretacja rzeczywistości zawarta $\mathrm{w}$ gramatyce i słowniku mówiących (Bartmiński 1999a:104)2. Językowy obraz świata jest inny dla każdego języka naturalnego, gdyż ludzie w różnorodny sposób ujmują myśli, interpretują zjawiska i sytuacje oraz wartościują rzeczywistość. Językowy obraz świata ,jest, więc dany, jest faktem, jest rzeczywistością, na której istnienie ciagle napotykamy, jest czymś realnym, prawdziwym, sprawdzalnym - możliwym do wykrycia, nie jest spekulacją myślową, nie można go nie brać pod uwagę w badaniach lingwistycznych" (Anusiewicz w: Bartmiński 1999b:274). ${ }^{3}$. Język stanowi nie

\footnotetext{
${ }^{1} \mathrm{~W}$ sądowym modelu odpowiedzialności człowiek jest odpowiedzialny za przedmiot odpowiedzialności przed instancją nakładającą na niego odpowiedzialość oraz bywa pociagany do odpowiedzialności przez trybunał odpowiedzialności i o tyle staje się odpowiedzialny.

${ }_{2}$ Bartmński podaje, że pojęcie językowego obrazu świata funkcjonuje $\mathrm{w}$ dwu wariantach: podmiotowym i przedmiotowym, którym przyporząadkować można wizje świata (view of the world) $i$ obraz świata (des sprachliche Weltbild). Wizja, czyli widzenie jest wizją czyjąś, zakłada patrzenie oraz podmiot postrzegający. Obraz, jest rezultatem również czyjegoś widzenia świata, punkt ciężkości zostaje w nim przesunięty ku przedmiotowi, którym jest to, co zawarte w samym języku. (ibidem).

${ }^{3}$ Bartmiński: „pojęciem językowego obrazu świata obejmuję zespół utrwalonych (stereotypowych) wyobrażeń o człowieku i świecie dający się odtworzyć z różnego typu danych językowych: gramatyczno-systemowych (kategorie fleksyjne, słowotwórcze, składniowe, tekstowe), semantyczno-systemowych (znaczenia wyrazów i jednostek
} 
tylko „formę myślenia”. Język ma wpływ na obraz rzeczywistości zgodnie z zawartym w nim światopoglądem, będącym zobiektywizowanym w skali narodu obrazem subiektywnych postrzeżeń indywidualnych (Grabias 2003:43). Dla Bartmińskiego niewątpliwie wartości są czynnikiem sterującym konstruowaniem wizji rzeczywistości przez subiekt doświadczający i konceptualizujący. Stanowią czynnik integrujący elementy obrazu świata utrwalone w tradycji i mające obieg społeczny. Wartości tworzą kulturową i społeczną tożsamość nosiciela języka. Sa obecne na tym poziomie konceptualizacji zjawisk, gdzie dochodzi do ich rozpoznania i szeregowania. Wartości są czynnikiem sterującym procesem kategoryzacji. Wyznawane wartości wyznaczają cel ludzkich działań, na poziomie dyskursu determinują funkcjonowanie bazowych pojęć (Bartmiński 2006:133-134, 143).

Autor Zasady odpowiedzialności, Jonas wyróżnił odpowiedzialność naturalną, kontraktową i supererogacyjną. W zaproponowaniej przez niego typologii odpowiedzialności odnajdujemy archetypiczny wzorzec odpowiedzialności naturalnej, np. rodzicielskiej, ustanowionej przez naturę, którą cechuje nieodwoływalność i niezależność od uprzedniego uznania czy wyboru, i która obejmuje całość bytu podmiotów i przedmiotów (zob. Jonas 1996:174-176). Zdaniem autora Zasady odpowiedzialności, odpowiedzialność mogą dźwigać tylko ludzie i tylko ludzie muszą ją dźwigać za inne potencjalne jednostki odpowiedzialności.

Dla Levinasa, współczesnego filozofa troski, odpowiedzialność rodzi się w akcie spotkania tyleż osobistego, co społecznego i kulturowego - z Innym, za którego bierze się odpowiedzialność prowadząc z nim dialog. Ludzie tematyzują (czynią przedmiotem dyskursu) i interpretują rzeczywistość. „Przedmiotowość ustanawia się w dyskursie, w rozmowie, która proponuje świat” (Levinas 2002:101). W zdaniu zjawisko przybiera postać tematu i zarazem traci swą zjawiskowość. Dla Levinasa bycie przedmiotem, tematem to bycie czymś, o czym można z drugim człowiekiem zawsze porozmawiać. Tematyzacja jako działanie jest apelem do uwagi człowieka (Levinas 2002:106 -107). Tym Innym (Spotkanym, „Pojawionym”) może być dziecko, stające twarzą w twarz z rodzicem, domagające się - poprzez samą swoją obecność - dialogu. Z Innym (dzieckiem) prowadzi się dialog oraz bierze się za niego odpowiedzialność. Przybiera to postać odpowiedzialności o charakterze substytucyjnym. Dziecko staje się twarzą rodzica, domagającą się troski (odpowiedzialności). Dziecko jest „byciem,” o którym można rozmawiać. Rodzic odpowiada za bycie dziecka, za kształt dialogowego doświadczenia, za siebie jako Innego. Spotkanie rodzica z dzieckiem to wydarzenie o charakterze fundamentalnym. Zarazem odpowiedzialność za dziecko konstytuuje się nie tylko w domu, ale także - z uwagi na uwarunkowania instytucjonalno-prawne w szkole. Dlatego tak bardzo na znaczeniu zyskuje edukacja aksjologiczna.

Odpowiedzialność nauczyciela, jako że ustanowiona przez nadanie lub przyjęcie zadania, jest odpowiedzialnością typu kontraktowego. Odpowiedzialność ta swą siłę czerpie z umowy i powiązana jest z powierzonymi jednostce obowiązkami. Treść i nominalny czas obowiązywania odpowiedzialności kontraktowej wyznaczane są przez empiryczną specyfikę powierzonego zadania, jednakże z odpowiedzialności tej można zrezygnować lub zostać z niej zwolnionym przez instancję nadrzędną, będąca stroną kontraktu (zob. Jonas 1996:175-176, 180). Jakie zadania mogą się składać na treść odpowiedzialności nauczycielskiej? Czy nauczycieli ograniczają w ich pracy dydaktycznej ramy programowe nauczania? Jednym z zadań pedagogów, których cechować musi dojrzałość osobista i szacunek dla poszukiwań aksjologicznego horyzontu podejmowanych przez uczniów, ma być „stwarzanie wychowankom sytuacji kształcących intelektualne rozpoznawanie wartości, ich nazwanie i uczciwe uzasadnianie ich miejsca w hierarchii uznanej przez pedagoga za prawdziwą, kształcenie uczuć wyższych dynamizujących realizację wartości coraz wyższych - tym samym coraz trudniejszych" (Olbrycht 1999:18).

Niewątpliwie na treść odpowiedzialności nauczyciela wpływ ma jego własny system wartości. W ramach filkowskej ontologicznej struktury odpowiedzialności (zob. Filek 1996:21), podmiot odpowiedzialności - nauczyciel, odpowiedzialny jest za edukację wychowanka. Nauczyciel odpowiada przed własnym rozumem na metapoziomie ideału wychowania (czy też przed

wielowyrazowych), użyciowych (należy pamiętać, że indywidualne teksty mają swój aspekt tekstowo-gramatyczny i gatunkowo-konwencjonalny, nie są tylko zjawiskami okazjonalnymi), a także danych „,przyjęzykowych”, wierzeniowych i zachowaniowych, które są relewantne dla efektywnej komunikacji” (Bartmiński 2006: 133). 
wewnętrznym poczuciem odpowiedzialności) a instancją nakładającą na nauczyciela odpowiedzialność jest społeczeństwo (rodzice), powierzające mu wychowanków. Czy przedmiotem odpowiedzialności nauczyciela jest wyłącznie edukacja wychowanka? Czy roli trybunału nie może pełnić dorosły wychowanek, nakładający na nauczyciela poczucie moralnej odpowiedzialności za kształt wiedzy i przekazany system wartości? Czy nauczyciele powinni kształcić uczniów zgodnie z panującym światopoglądem, czy może raczej należałoby pozwolić uczniom na samodzielne poszukiwania prawdy?

Zobaczmy jak wygląda podręcznikowa propozycja nauczania i kształtowania odpowiedzialności wśród uczniów kierowana do nauczycieli. Jedną z takich propozycji tematycznych lekcji odnajdujemy w Edukacji filozoficznej w gimnazjum (Jedynak, Walentynowicz 2001). W podręczniku tym obecne jest zagadnienie wartości i postaw życiowych. Autorzy dokonują rozróżnienia na: „odpowiedzialność” i „odpowiedzialną postawę”. „Odpowiedzialność” rozumiana jest jako „obowiązek przewidywania moralnych skutków własnych czynów i takiego planowania działań, by te skutki były dobre”. „Odpowiedzialna postawa” zaś, to dazżenie do wypełnienia powyższego obowiązku (obowiązku odpowiedzialności; Jedynak, Walentynowicz 2001:14). Tematyka zajęć z odpowiedzialności moralnej człowieka za własne czyny została zakwalifikowania w Edukacji filozoficznej $w$ gimnazjum, do modułu zajęć związanych $\mathrm{z}$ wychowaniem obywatelskim. Przewidywanym celem tych zajęć jest osiągnięcie przez uczniów świadomości odpowiedzialności za siebie i własne czyny. Za sprzyjające w kształtowaniu odpowiedzialnej postawy autorzy uważają: wiedzę dotyczącą tego, co jest moralne, zdolności przewidywania skutków własnych działań oraz wrażliwość i intuicję moralną, zwaną sumieniem. W ramach zajęć na temat odpowiedzialności i odpowiedzialnej postawy, proponuje się postawić młodzieży poniższe przykładowe pytania do rozważenia: czy uwarunkowania genetyczne, środowiskowe, historyczne itp., ograniczają ludzką wolność, czy mają wpływ na zmniejszanie odpowiedzialności, czy powinny mieć wpływ na wymiar kary dla przestępców, jaki charakter ma/powinna mieć odpowiedzialność w okolicznościach nadzwyczajnych (śmierć, ból, wojna)? (Jedynak, Walentynowicz 2001:14, 33, 51).

O aksjodeontologicznym wymiarze pracy nauczyciela pisze A. M. de Tchorzewski. Z jednej strony nauczyciel wyposaża ucznia w wiedzę i umiejętności pozwalające mu przystosować się do życia $\mathrm{w}$ społeczeństwie. $\mathrm{Z}$ drugiej strony praca nauczyciela ma wymiar aksjologiczny - to wartości, stanowią źródło celów jego pracy oraz leżą u podstaw etyczno - deontologicznych problemów zawodu nauczyciela. Odpowiedzialność jako kategoria aksjodeontologiczna stanowi podstawową cechę postępowania człowieka wobec człowieka, tym samy jest źródłem powinności i obowiązku moralnego. Odpowiedzialność nauczyciela jest warunkiem jego zawodowej dojrzałości (zob. Tchorzewski 1998:90-98). A jeśli nauczyciele zorientowani są głównie na realizacje zadań wynikających z programu nauczania? Czy takie podejście do nauczania przez wychowawcę rozwija w podopiecznych przekonanie o własnych możliwościach oraz potrzebach?

$\mathrm{W}$ pracy dydaktyczno-wychowawczej w szkole, nauczyciel musi pamiętać, że słowem oddziaływuje na uczniów. Słowem przekazuje im wiedze o świecie i dla adekwatnego odzwierciedlenia rzeczywistości powinien jak najwłaściwiej się nim posługiwać. Zawód nauczyciela należy do profesji o antropotwórczym znaczeniu. Sposób operowania językiem w procesach edukacyjnych ma wpływ na jakość rozwoju generowanego przez szkołę. Procesy dydaktyczne wiążą się z wyrażaniem, nadawaniem, interpretowaniem i przetwarzaniem szerokiego spektrum znaczeń. Na efektywność działań edukacyjnych wpływ swój mają więc umiejętności porozumiewania się (Śnieżyński 2005:53). Korzyści w sferze dydaktycznej może przynieść zastosowanie w praktyce edukacyjnej dialogu, jako metody kształcenia. Dialog jako idea przewodnia ma nieść ze sobą korzyści także w sferze wychowania. Dialog ten wymaga wzajemnej otwartości, uczciwości oraz cierpliwości z uwagi na fakt iż nie od razu wczuwamy się w świat znaczeń drugiego człowieka (Śnieżyński 2005:96, 104). Dialog staje się metodą postępowania w pracy z młodzieżą, metodą na uzyskanie wglądu w ich świat wartości i ukazanie im własnego. Staje się sposobem kształtowania postaw i przekonań. Staje się wreszcie, przesłanką dla odpowiedzialnego przypisania nauczycielowi odpowiedzialności perlokucyjnej.

Ostatni rodzaj jonasowskiej odpowiedzialności, odpowiedzialność supererogacyjną cechuje fakt, iż dobro, za które człowiek nie jest (jeszcze) odpowiedzialny, czyni on przedmiotem 
swobodnie wybranej odpowiedzialności. Z życzenia sobie tej odpowiedzialności, jednostka zdobywa konieczną dla jej urzeczywistnienia moc jak również i obowiązek (Jonas 1996: 177). Od rozstrzygnięcia pytania czy bycie nauczycielem to powołanie czy zwyczajny zawód, zależy przyjęcie bądź odrzucenie supererogacyjnej postawy w edukacji moralnej. Można przyjąć postawę bycia odpowiedzialnym za powierzone zadanie przez okres semestru, bądź można spojrzeć na zagadnienie $\mathrm{w}$ świetle długofalowego kształcenia społeczeństwa i ująć je wraz z poczuciem misji do zrealizowania. Misja wychowawcy polega na piętnowaniu głupoty, ksenofobii oraz mówieniu prawdy. Podstawową kategorią jest tolerancja, która sprzyja trwaniu różnorodności, „moralnego piękna różnic", stanowiącego wartość naczelną (Wawrzyniak 2002:218). Supererogacyjna odpowiedzialność swoje źródło ma w poświęceniu i miłosierdziu. Niewątpliwie związana jest $\mathrm{z}$ braniem na „swoje barki” z własnej nieprzymuszonej niczym woli, odpowiedzialności za działanie i jego skutki dla innych ludzi.

\section{Zagadnienie odpowiedzialności perlokucyjnej}

Wspomniane już wyżej zagadnienie odpowiedzialności perlokucyjnej swoją siłę czerpie ze wskazanego faktu, iż językiem możemy kształtować rzeczywistość tak skutecznie jak przy pomocy innych środków. Przeprosinami, przyrzeczeniami nie tylko zmieniamy rzeczywistość, ale i powodujemy zmiany $\mathrm{w}$ stanie mentalnym odbiorcy (Lachur 2004:260). Nie bez znaczenia pozostaje, że wypowiedzi sprzyjają powstawaniu emocji, które mają swoje przykładowe źródło w wartościowaniu wypowiedzi nadawcy przez adresata. Na powstającą emocję nakłada się reakcja, będąca wypowiedzią adresata (sygnalizuje efekt perlokucyjny typu mentalnego). Analiza perlokucji na ogół zawęża się do zamierzonych efektów perlokucyjnych, pomijając rzeczywisty efekty perlokucyjne z powodu ich mnogości i nieprzewidywalności. Można analizować zamierzone efekty perlokucyjne $\mathrm{z}$ uwagi na wskaźniki stanów emocji (mogące być wyrazem zamierzonych i niezamierzonych efektów perlokucyjnych), bądź zamierzone werbalnie działania nadawcy. Nauczyciel może dobierć środki i sposoby językowego wyrazu dla wyrażenia określonych intencji i wywołania pożądanego skutku perlokucyjnego, zgodnie ze swoim doświadczeniem komunikacyjnym (zob. Majewska 2005:24-28).

Autor Czynności mowy wyróżnił pięć typów aktów mowy: stwierdzenia, dyrektywy, zobowiązania, autoekspresje i deklaracje. Zdaniem J. Searla, wypowiadanie słów to wykonywanie czynności wypowiadania; odnoszenie się i orzekanie to wykonywanie czynności zdaniowych; stwierdzanie, zapytywanie, rozkazywanie, obiecywanie to wykonywanie czynności illokucyjnych. „Z pojęciem czynności illokucyjnych wiąże się pojęcie następstw lub skutków, jakie takie czynności mogą mieć dla działań, myśli, przekonań itd., słuchających je osób. Na przykład, argumentując mogę naktonić czy przekonać kogoś, ostrzegając mogę go przestraszyć lub zaalarmować, prosząc mogę sktonić go do zrobienia czegoś, informując go mogę mu coś uzmystowić (...). Wyrażenia wyróżnione oznaczają czynności perlokucyjne" (Searle 1987: 37-39; Nęcki 2000:60-62; Galasiński, 1992:16). Czynność perlokucyjna obejmuje następstwa zamierzone lub niezamierzone. Searle za istotną cechę zjawiska komunikacji językowej uznał akt językowy. Twierdzi, że to użycie w konkretnej sytuacji słowa, zdania czyni z niego jednostkę komunikacji językowej. Za podstawową jednostkę komunikacji językowej uważa akt illokucji. Cel aktu mowy zdaniem J. Searla ,jest tożsamy z celem illokucyjnym aktu illokucyjnego" a illokucja dotyczy skutków tego jak akty mowy wpływają na ludzkie działania i myśli. „Argumentując coś czymś”, można „przekonywać” do czegoś lub coś ,perswadować” komuś (zob. Majewska 2005:20-21). Przypisywane wypowiedziom językowym znaczenie illokucyjne, interpretowane jest w kategoriach intencji i ocen, wynikających z relacji zachodzących pomiędzy uczestnikami aktów komunikacji. „Relację między aktem illokucyjnym a aktem perlokucyjnym można określić jako reakcję typu „poprzednik - następnik”, co ma oznaczać, że „poprzez powiedzenie X, robię Y”. „Powiedzenie X,” odnosi się do illokucji, natomiast ,zrobienie Y”, odsyła do perlokucji. Efekt w postaci aktu perlokucyjnego jest każdorazowo rezultatem działania illokucyjnego (zob. Duszak 1998:27 za: Przybyla 2004:12, 21).

Teorie aktów mowy J.L. Austina wykorzystuje J. Habermas. Obok istnienia w języku wypowiedzi konstatujących, będących na ogół stwierdzeniem faktu, obecne są także, na co zwrócił 
uwagę właśnie J.L .Austin, wypowiedzi performatywne wskazujące na wykonanie działania. J. Habermas przyjmuje za Austinem, że akty te można podzielić na: lokucje, dające się scharakteryzować jako „coś mówić”, illokucje oznaczające : „,coś czynić, mówiąc” i perlokucje odnoszące się do tego, że „coś się sprawia przez to, że się działa coś, mówiąc” (zob. Habermas 1999:478; Retter 2005:51-52) ${ }^{4}$. Zdaniem J. Habermasa całej jego teorii działania komunikacyjnego przyświeca wizja językowego dochodzenia do porozumienia jako mechanizmu koordynacji działań. Do działania komunikacyjnego zalicza językowo zapośredniczone interakcje, w których uczestnicy czynnościami językowymi zmierzają do realizacji tylko celów illokucyjnych, zaś takie interakcje, w których przynajmniej jeden z uczestników chce za pomocą czynności językowych wywołać u partnera efekty perlokucyjne, traktuje jako działanie strategiczne. Dla J. Habermasa perlokucje związane są z tym celem czynności, których nie zdradza się uczestnikom i dzięki czemu wprowadza się ich w błąd, by osiagnąć strategiczną korzyść. Niejawne, oszukańcze oddziaływania - perlokucje, Habermas ocenia jednoznacznie negatywnie. Nadto perlokucje są dla niego częścią działania teleologicznego i nie dają się pogodzić $\mathrm{z}$ działaniem komunikacyjnym. Tylko oddziaływania ujawnione i zaakceptowane przez uczestników dzięki dobrowolnie podjętej decyzji Habermas zalicza do działania komunikacyjnego. Perlokucje dla J. Habermasa to specjalna klasa „,interakcji strategicznych”. Illokucje artykułowane są w sposób jawny natomiast do perlokucji w żaden sposób nie wolno się przyznawać. „Efekty perlokucyjne są oznaką integrowania czynności językowych w konteksty właściwe interakcji strategicznej" (Habermas 1999:482-487; Retter 2005:53).

Przy takim rozumieniu perlokucyjności, jako aktów mowy, które mają na celu wprowadzenie w błąd partnerów rozmowy celem osiagania korzyści, odpowiedzialność staje się „odpowiedzialnością za manipulacje”. Relacja z „ty” w oddziaływaniach jawnych ukierunkowywana jest na porozumienie, zaś przy oddziaływaniu utajonym na zmanipulowanie celem osiagnięcia korzyści. Wiążę się to z potraktowaniem człowieka jako środka do celu a nie jako celu samego w sobie. Odejście od kantowskiego imperatywu praktycznego, na rzecz działań zgodnych z myślą: „Jeśli chcesz A, to powinieneś B," wyłania się przy działaniach manipulatorskich. Przeświadczenie o negatywności używania manipulacji i niechęci w stosunku do bycia manipulowanym przez Innych charakterystyczne dla działań jawnych, stara się być zgodne z kantowskim imperatywem kategorycznym.

Obok oddziaływań jawnych i manipulacyjnych w przestrzeni międzyludzkich interakcji można dostrzec oddziaływania nie będące zamierzonymi, czy umyślnymi tzw., czyny „niechcące”. Czy czyny te wpisują się w ramy ontologicznej struktury odpowiedzialności? Czyż nie jest tak, że chcąc / nie chcąc, przy zachowaniu ostrożności można także spowodować aktem mowy „niechcący” stan rzeczy? Istotne jest, że w przypadku czynów niezamierzonych mamy na ogół do czynienia $\mathrm{z}$ nieostrożnością sprawcy czynu. Mogą być one wyrażone i w formie na przykład efektu perlokucyjnego przejawiającego się urażaniem, jak też mogą przybrać formę złożenia zobowiązania. Autorem hipotezy głoszącej, że każde użyte zdanie posiada element performatywny jest J. R. Ross. Performatywność zdawać się może, że jest ograniczona do zdań rozpatrywanych w użyciu, w ramach pragmatycznego aspektu opisu języka. Badania językowe postulują uwzględnienie tego podejścia także w analizach syntaktycznych. Hipoteza Rossa zwana analiza performatywna, głosi, że „w strukturze głębokiej każdego zdania występuje czasownik performatywny w pierwszej osobie czasu teraźniejszego strony czynnej” (zob. Muszyński 1988:144).

Każda decyzja spełniająca warunek świadomego wyboru i namysłu działającego, zasługuje na kwalifikację ocenną z uwagi na problematykę odpowiedzialności. Odpowiedzialność perlokucyjna jest odpowiedzialnością będącą rezultatem mówienia, myślenia i czynienia. Jak ”istnieje

\footnotetext{
${ }^{4}$ J. L. Austin w: „Jak działać słowami”, stwierdza, że: „Powiedzenie czegoś wywołuje często, a nawet normalnie, w następstwie pewne skutki w sferze uczuć, myśli lub działań słuchaczy, lub mówiącego, bądź innych osób, a powiedzenie to może być wygłoszone z przeznaczeniem, intencją lub zamiarem wywołania owych skutków. Możemy też wówczas powiedzieć, że mówiący wykonał pewną czynność, a stosując jej nazewnictwo bądź tylko pośrednio dokonał odniesienia do pewnej czynności lokacyjnej lub illokucyjnej, bądź też w ogóle go nie dokonał. Wykonanie czynności tego rodzaju będziemy nazywać wykonaniem czynności „perlokucyjnej”, a czynność wykonaną (...) „perlokucją”. (Austin 1993:646647)
} 
odpowiedzialność za słowo wypowiadane, tak też istnieje odpowiedzialność za odbiór słowa" (Puzynina 1997:259). Taki akt illokucyjny jak obietnica może stać się zaczynem innego aktu mowy jak perlokucja. Obietnica złożona $\mathrm{X}$-wi, akt czysto illokucyjny to nie tylko złożenie obietnicy i obowiązek jej dotrzymania. J. R. Ross wyróżnił obowiązki prima facie, oraz obowiązki właściwe (Dancy w: Singer 2002:261-270). Rozważa on sytuację, kiedy to jednemu obowiązkowi zostaje przeciwstawiony inny. Obietnica może sprowokować niezamierzone działania i stać się następstwem pewnych skutków. Działanie może być efektem stwarzania czegoś, tylko przez to, że się „coś” mówi. Przy aktach illokucji, nadawca coś robi mówiąc, podlega odpowiedzialności ocennej za świadome i wolne działania. Przy aktach perlokucji, jest odpowiedzialny za stwarzane fakty społeczne. Sam zaś charakter owego stwarzania może być mniej lub bardziej uświadomiony.

Z wyróżnionych przez J. Austina aktów mowy najwięcej nieporozumień wzbudzały perlokucje. Kontrowersje budziło, czy do aktu mowy zalicza się rzeczywiste zmiany wywołane wypowiedzią, czy też tylko stan mentalny odbiorcy. Ograniczenie perlokucji do stanu mentalnego też nie dawało jasności, bo stan mentalny odbiorcy ulega zmianie na skutek wypowiedzi w sposób nie zamierzony przez nadawcę. Pytanie te znalazły swój wydźwięk w tworzeniu kryteriów odróżniania semantyki i pragmatyki. Wiedza oraz doświadczenie mówiących decydują o tym, że ta sama wypowiedź raz może zostać odczytana jako aluzja, ironia a innym razem jako metafora. Istnieją wyrazy, które nie tylko nazywają pewne czynności, cechy obiektywne ale zarazem są one oceniane negatywnie (np., kłamać, kraść, zdradzać, donosić). Co charakterystyczne, dołączany jest do znaczenia tych wyrazów element oceny a ich wartość zróżnicowana jest środowiskowo. W samej ocenie zjawisk mogą zachodzić istotne różnice między mówiącymi (zob. Grzegorczykowa 1988:122-125).

Kolejny problem stanowi pytanie, czy za przebieg ludzkich interakcji odpowiedzialni są tylko nadawcy komunikatu? Czy odpowiedzialność za pomyślny przebieg dialogu edukacyjnego nie wymaga zapytania o współodpowiedzialność i nauczyciela i uczniów za przebieg procesów edukacyjnych? Zagadnienie współodpowiedzialności (nie tylko rozumianej w sensie nabywanej kwalifikacji ocennej) ujawnia się zazwyczaj w przypadku działań zespołowych. Niektóre współdziałania cechuje możliwość szybkiej obserwacji następstw czynów, inne są rozciagnnięte mocno w czasie i dostępne nie wprost dla obserwacji. Komunikacja między ludźmi przypomina siatkę wzajemnych relacji i powiązań. Niezależnie od woli ludzie oddziaływają na swoje postawy i doznania, gdyż język stanowi nośnik wartości oraz narzędzie komunikacji także w edukacji w szkole. Chęć prowadzenia żywego dialogu z uczniem, z dzieckiem, czy z pacjentem wymaga szerokich umiejętności oraz wiedzy. Obok mówienia o poczuciu odpowiedzialności nauczyciela warto także czasem zadać pytanie o poczucie odpowiedzialności u podopiecznego i to, nie tylko w stosunku do rezultatów jego aktywności ale także w uwagi na dbanie przez niego o swój rozwój umysłowy oraz własne zachowania i postawy względem siebie i innych.

Przenosząc pojęcie działania na płaszczyznę rozważań dydaktycznych, zgodnie z myślą iż „istotne cechy ogólnego pojęcia X (kategorii X) przysługują pojęciom podrzędnym Y” (Kojs 1987:37) zauważamy, że wśród działań dydaktycznych, działaniem podstawowym jest uczenie się. Cz. Kupisiewicz podaje, że „przez uczenie się będziemy rozumieć proces zamierzonego nabywania przez uczący się podmiot określonych wiadomości, umiejętności i nawyków, dokonujących się $\mathrm{w}$ toku bezpośredniego i pośredniego poznawania rzeczywistości” (Kupisiewicz 1976:20). Natomiast dla W. Okonia uczenie się jest procesem „w którym na podstawie poznania, doświadczenia i ćwiczenia powstają nowe formy zachowania się i działania lub zmieniają się stare" (Okoń 1970:10). W. Kojs stwierdza, że uczenie się można ująć jako proces świadomy, zamierzony i czynny, dokonywany poprzez bezpośrednie lub pośrednie poznanie rzeczywistości, doświadczenia i ćwiczenia, w wyniku którego podmiot uczący się nabywa wiadomości, nawyki i umiejętności. Na rezultat uczenia się składają się wiadomości, których zdobywanie wymaga wyćwiczonych uzdolnień, potrzebnych do rozporządzania wiadomościami oraz panowania nad nimi (Kojs 1987:39).

Formami działań społecznych w pracy nauczycielskiej są nauczanie i kształcenie. Ludzkie zachowanie dopasowuje się do dominujących w danym społeczeństwie standardów. Nauczanie występuje „w postaci czynności okazjonalnych i przypadkowych, jak i w tych sytuacjach, kiedy jest to systematyczne, planowe, bezpośrednie kierowanie procesem uczenia się" (Kupisiewicz 
1976:21). W. Kojs podaje, że (np. dla H. Muszyńskiego) nauczanie jest przyswajaniem uczniowi technik najskuteczniejszego działania. To również kształtowanie dyspozycji, które mają gwarantować powodzenie $\mathrm{w}$ dążeniu do stawianych celów. Natomiast kształceniu przyświeca zapoznawanie uczniów z dorobkiem kultury, z wiedzą o przyrodzie i społeczeństwie. To takie kształtowanie umiejętności, rozwijanie zainteresowań, zdolności: myślenia, spostrzegania, pamięci, wyobraźni oraz wpajanie wartościowych zasad postępowania, które zapewnić ma intelektualny rozwój dzieci, młodzieży i dorosłych. Kształcenie i nauczanie to społecznie wyodrębnione i uwarunkowane „wielopodmiotowe działania złożone, składające się z działań nauczyciela i uczniów, zróżnicowanych pod względem posiadanych zasobów informacyjnych, (...) które mają na celu zlikwidowanie w pewnym stopniu tychże różnic" (Kojs 1987:65-66, 71). Skuteczne oddziaływanie nauczycieli na uczniów nie może odbywać się bez wyczulenia na kompetencję i wiedzę językową. Obecność świadomości językowej stanowi element kluczowy przy podejmowaniu decyzji jak najskuteczniejszego oddziaływania nauczyciela na wychowanków.

\section{Kompetencja językowa i komunikacyjna w pracy nauczyciela}

Kompetencja językowa (pojęcie pochodzące od N. Chomsky'ego), dotyczy struktury języka, pozwalającej na wytwarzanie własnych i rozumienie cudzych wypowiedzi w tym języku. Dla Chomsky'ego to zdolność użytkownika jakiegoś języka naturalnego do rozumienia i tworzenia zdań w tym języku. Twórczy charakter kompetencji językowej przypada tylko składnikowi syntaktycznemu, gdyż składniki fonologiczny i semantyczny sprawują tylko interpretacyjną rolę. Za jednostkę kompetencji językowej obrane zostaje zdanie z obecnym mu sądem (Kurcz 2000:16). Kompetencja językowa zdaniem A. Heinza, polega na ,intuicyjnej znajomości określonego zbioru reguł eksplicytnych i uporządkowanych, pozwalających w oparciu o istniejący słownik: 1) generować, czyli tworzyć, oraz rozumieć, nowe zadania dotąd niezrealizowane, a równocześnie 2) rozstrzygać o ich gramatyczności, czyli przynależności do danego języka (poprawności formalnej), lub niegramatyczności, 3) decydować, czy dane dwie struktury są z punktu widzenia znaczeniowego identyczne, czy różne, wreszcie 4) wyprowadzać z intuicji mówiących tkwiący w niej system gramatyczny danego języka" (Heinz 1978:408 za: Wołos 2002:45). Kompetencja językowa ma dla I. Kurcz, charakter wiedzy utajonej (uwarunkowania biologiczne w postaci Uniwersalnej Gramatyki) oraz wiedzy jawnej (metajęzykowej). Podstawową funkcją kompetencji językowej jest funkcja reprezentatywna (przedstawieniowa) wobec rzeczywistości (Kurcz 2005:111). Jak stwierdza D. Hymes, osoba zdolna wyłącznie do budowania poprawnych gramatycznie wypowiedzi, bez dostosowania do kontekstu społecznego ich występowania, mogłaby zostać poczytana za szaleńca (Hymes 1960:109). Przesunięcie zainteresowań z reprezentatywnej $\mathrm{ku}$ komunikacyjnej funkcji języka zaowocowało pojęciem kompetencji komunikacyjnej.

Dell Hymes w opozycji do gramatyki generatywno-transformacyjnej zaproponowat pragmatyczne podejście do badań. Zauważa, że aby zrozumieć zachodzące w komunikacji codziennej procesy nadawania znaczeń nie wystarczy sama kompetencja językowa. Stawia pytanie - „co dziecko przyswaja ucząc się mówić poza regułami gramatycznymi oraz słownictwem; w jaki sposób staje się w pełni rozwiniętym członkiem społeczności językowej, do której przynależy" (Hymes 1960:101)? W poprawności gramatycznej zdań upatruje tylko warunku wstępnego porozumienia. Zauważa, że ta sama konstrukcja przyjmuje różne znaczenia w zależności od kontekstu, w jakim się pojawia (zob. Hymes 1960:105). Wprowadzone przez niego pojęcie kompetencji komunikacyjnej odnosi się do użycia języka z uwagi na określoną sytuację i kontekst społeczny, oraz odpowiednio do zachowań innych uczestników interakcji komunikacyjnej. Kompetencja komunikacyjna zostaje zdefiniowana jako: „zdolność do wyboru z całości repertuaru poprawnych gramatycznie wypowiedzi tych, które odzwierciedlają normy społeczne kierujące zachowaniem w danych okolicznościach" (Kurcz 2001:139-140). Za jednostkę analiz językowych zostaje obrana na miejsce zdania, ,wypowiedź”. W „wypowiedzi” mamy do czynienia nie tylko z sądem, obecnym także w zdaniu, ale co ważne z aktem mowy, który wyraża intencje mówiącego (Kurcz 2000:17). Element jawny kompetencji komunikacyjnej, zwany wiedzą metapragmatyczną pozwala na świadome korzystanie $\mathrm{z}$ reguł dyskursu $\mathrm{i}$ formułowanie odpowiednich teksów 
mówionych i pisanych (Kurcz 2005:112). Kto ma na uwadze efektywność porozumiewania się językowego, kto zważa na sytuację społeczną oraz uwzględnia cechy, cele oraz postawy innych, ten nie przechodzi obojętnie obok zagadnienia kompetencji komunikacyjnej.

Kompetencje komunikacyjną można uznać za warunek wszystkich społecznych zachowań językowych. D. Hymes w zakresie znaczeniowym tego pojęcia widzi cztery komponenty, od których zależeć ma decyzja o znaczeniu i o formalnym kształcie wypowiedzi. Są to potencjał systemowy, wykonalność, występowanie i odpowiedniość (Grabias 2003:36-37). Budując wypowiedź użytkownik języka, jak podaje S. Grabias, może postawić następujące pytania: czy wypowiedź jest możliwa w danym systemie językowym (potencjał systemowy); czy możliwa jest ze względu na psychiczną i społeczną sytuację mówiącego (wykonalność); czy i w jakim stopniu jest społecznie realizowana (występowanie); czy i w jakim stopniu jest w danym kontekście społecznym skuteczna (odpowiedniość)? (Grabias 2003: 37).

I. Kurcz kompetencje: językową i komunikacyjną nazywa wiedzą językowa, chociaż stosowany bywa też termin „władza językowa” (zob. Kurcz 2005:113). Czynią tak Hauser, Chomsky i Fitch w zamieszczonym w 2002 r., w ,Science” artykule: The faculty of language. What is it? Who has it? Haw did it evolve? Autorzy rozróżnili tam władzę językową w sensie wąskim oraz szerokim. Władzę językową w sensie wąskim tworzy Uniwersalna Gramatyka, a zasadą naczelną jej funkcjonowania jest zasada rekurencji. Władza językowa w szerokim sensie obejmuje obok tej pierwszej także dwa systemy, będące na usługach naszej zdolności do posługiwania się językiem, określane jako sensoryczno-motoryczny (percepcja i wytwarzanie mowy) i pojęciowo-intencjonalny (przekazywanie znaczeń i kryjących się za tym intencji komunikacyjnych, por. Hauser, Chomsky, Fitch 2002:1569-79 za: Kurcz 2005:113) . $^{5}$

$\mathrm{Na}$ czym polega kompetencja komunikacyjna nauczyciela? Na pewno wyraża się ona skutecznością zachowań językowych w edukacyjnych sytuacjach. Nauczyciel kompetentny komunikacyjnie posiada: wiedzę o komunikowaniu interpersonalnym, umiejętności słuchania i empatii oraz potrafi wykorzystać techniki dyskusyjne wraz $\mathrm{z}$ językiem niewerbalnym $\mathrm{w}$ porozumiewaniu się z uczniem. Potrafi on wzbudzać wrażliwość językową wychowanków i dostosować styl pracy uczniów do poziomu ich rozwoju. Ale to nie wszystko. Dla dyskursu edukacyjnego dobrze jest, gdy nauczyciel doskonali poprawność, czytelność i prostomyślność własnych zachowań językowych, jakie składają się na etykę mowy (Denek 1999:151).

Niewątpliwym celem kultury jest wychowanie człowieka. Troska o wartości powierzana zostaje edukacji. Proponowana przez M. Śnieżyńskiego koncepcja edukacyjna zwana sztuką dialogu ma za zadanie prowadzić do okrywania prawdy o człowieku i świecie. Dialog sprzyja wzbogacaniu się wewnętrznemu ludzi oraz uczy tolerancji. W dialogu edukacyjnym nauczyciel przestaje być jedynie przekazicielem wiedzy, i zaczyna być doradca, inspiratorem, „Sokratesem” pomagającym uczniom odkryć prawdę. Zaznaczyć należy, że zaistnienie takiego dialogu nie jest sprawą łatwą. Wymaga on bowiem nawiązania kontaktu z uczniem - tutaj swoje miejsce ma komunikacja, a następnie wzbogacenie jej relacjami interpersonalnymi z uwzględnieniem zasady podmiotowości. Dopiero w takich warunkach może narodzić się wspomniany dialog edukacyjny. Autor, zauważa, że mówienie o wychowaniu człowieka bez oparcia tego wychowania o wartości, sytuuje wychowanka poza współrzędnymi dobra i zła. Odniesienie do wartości pozwala na uzmysłowienie sobie przez człowieka jego własnej odpowiedzialności (Snieżyński 2005:10-19).

Zagadnienie kompetencji podkreśla znaczenie dyskursu aksjologicznego. Dyskurs aksjologiczny to „tekst powstały w wyniku komunikowania treści wartościujących lub wypowiedzi na temat wartości”. Dyskurs aksjologiczny składa się na dyskurs edukacyjny (dydaktyczny) w ramach, jakiego odbywa się proces przekazywania wiedzy. Stwarzanie podczas zajęć dydaktycznych sytuacji o charakterze aksjologicznym sprzyja podkreślaniu i przeżywaniu wartości przez uczniów. Językowy świat wartości pełni nadrzędną funkcję w językowym obrazie świata. Rozwijanie kompetencji aksjolingwistycznej wiąże się z przekształceniami w ramach kompetencji językowej - rozpoczętej w nauce szkolnej i kompetencji docelowej - odpowiadającej gramatyce dorosłego w zakresie leksykalno-gramatycznym, komunikacyjnym i kulturowym. Szkolnemu dyskursowi aksjologicznemu nie obce powinno być pragnienie nabywania przez uczniów języka

\footnotetext{
${ }^{5}$ Schemat całościowej wiedzy językowej podanej przez I. Kurcz (2005:124)
} 
wartości, rozwijania kompetencji komunikacyjnej oraz kulturowej (zob. Mrózka 2000:44-46). Świat wartości odzwierciedlony w języku stanowi istotny składnik językowego obrazu świata $z$ jakim człowiek spotyka się już od najmłodszych lat swojego życia. Ta potrzeba nazywania i mówienia o wartościach rozwija kompetencję aksjolingwistyczną, która stanowi fundament dla myślenia o wartościach i dla działania w odniesieniu do świata wartości. W dyskursie nie tylko dydaktycznym kompetencja aksjolingwistyczna stanowi element niezbędny dla świadomego przekazywania $\mathrm{w}$ tym i nauczania wartości. Jest ona koniecznym narzędziem dla kreowania podczas zajęć dydaktycznych przez nauczyciela takich sytuacji aksjologicznych, które moga sprzyjać pobudzeniu myślenia o wartościach, ukazywaniu ich w wielorakich kontekstach sytuacyjnych oraz przeżywaniu przez uczniów.

\section{Zakończenie}

Na związkach pomiędzy aktami mowy a wartościowaniami koncentruje się aksjolingwistyka a jej wyniki dają się zastosować do praktyki życia społecznego. Dla aksjolingwisty interesująca jest rola języka $\mathrm{w}$ procesie wartościowania rzeczywistości. Aksjolingwista patrzy na światopoglądowotwórczą rolę języka. Bada sposoby przemycania wartościowań za pomocą języka. Odtworzenie obrazów świata istniejących w ludzkich umysłach, odszyfrowanie i zinterpretowanie utrwalonych, w każdym języku systemów wartości, jest niebłahym zadaniem.

Obraz świata dany jest wraz z językiem w procesie socjalizacji. Jako potoczna interpretacja rzeczywistości, językowy obraz świata odpowiada potrzebom człowieka. Nie stanowi jedynie interpretacji rzeczywistości ale reguluje postawy i sposoby działania ludzi wobec tak postrzeganej rzeczywistości. Językowy obraz świata ujawnia wartości obowiązujące wśród użytkowników danego języka, które wyrażane mogą być nie wprost, w przenośnych znaczeniach słów. Zamiast podejmować próby budowy hierarchizacji i klasyfikacji wartości dużo owocniejsze okazać się moga badania konkretnych zjawisk jak np. wstydu czy dumy. Pozwala to na dostrzeżenie ich społecznej roli oraz znaczenia jakie odgrywają w określonym miejscu i czasie. Znajomość tych samych pojęć przez uczestników komunikacji i podobne mechanizmy wartościowania stają się warunkiem skutecznego porozumiewania się. Język człowieka to widoczne świadectwo jego systemu wartości. Dostrzeżenie różnic między znaczeniem: „niechęć”, „nienawiść”, „odraza”, „wstręt”, „awersja” pozwala na dostrzeżenie różnorodności emocji, kierujących ludźmi. Sprawą otwartą pozostaje, czy język indywidualnego człowieka jest adekwatny do jego poziomu rozwoju moralności, czy sposób rozumienia znaczeń pojęć etycznych nie odzwierciedla rodzaju etyki w ujęciu Kohlberga?

Poprzez wypowiadane słowa nauczyciele mogą oddziaływać na uczniów, motywować ich do pewnych zachowań oraz wzbudzać chciane, bądź przypadkowe emocje. Orientacja nauczycieli na wartości przydatne społecznie wskazuje, że nauczyciele podejmują się dydaktycznowychowawczego wyposażenia wychowanków w pewne minimum aksjologiczne, pozwalające im na samodzielne funkcjonowanie w społeczeństwie. Tak kształtowane osoby nie są „produktem skończonym". To od poszczególnego ucznia zależy jakim będzie się stawał w dalszym życiu. Czy współczesna szkoła starając się sprostać wymaganiom rynku docenia zarazem rangę kompetencji i społecznych umiejętności komunikacyjnych (z uwzględnieniem performatywnej funkcji wypowiedzi normatywnych) uczniów i tym samym stawia sobie wyraźne zadania dydaktyczne w tym obszarze? Przecież nauczyciel ma obowiązek przekazywania wiedzy oraz umiejętności uczniom. Niejednokrotnie jednak od nauczyciela oczekuje się, że będzie także wychowywał, że podejmie się zadań zdających się spoczywać „w rękach” rodziców. I niezależnie od tego, czy nauczyciel podejmie się tych zadań, czy też nie, nie zmieni to faktu, że w swojej pracy dydaktycznej operuje językiem, przy użyciu którego wartościuje rzeczywistość. Dla odpowiedzialności perlokucyjnej ważne jest, że on to czyni (niezależnie nawet od chęci) mową. 


\section{Bibliografia}

Anusiewicz, J., 1999: Problematyka językowego obrazu świata w poglądach niektórych językoznawców i filozofów niemieckich XX wieku w: Bartmiński, J., (red.), 1999(a).

Austin, J.L., 1993: Mówienie i poznawanie. Rozprawy i wyktady filozoficzne, Warszawa: Wyd. Naukowe PWN.

Bartmiński, J. (red.), 1988: Konotacja, Lublin: UMCS.

Bartmiński, J. (red.), 1999(a): Językowy obraz świata, Lublin: UMCS.

Bartmiński, J. 1999(b): Punk widzenia, perspektywa, językowy obraz świata, w: Bartmiński, J. (red.), 1999(a).

Bartmiński, J., 2006: Językowe podstawy obrazu świata, Lublin: UMCS.

Dancy, J., Etyka obowiązków prima facie, w: Singer, P (red.), 2002: Przewodnik po etyce, Warszawa: Książka i Wiedza.

Denek, K., 1999: Aksjologiczne aspekty edukacji szkolnej, Warszawa: Wyd. Adam Marszałek.

Duszak, A., 1998: Tekst, dyskurs, komunikacja międzykulturowa, Warszawa. (za:) Przybyla, O., 2004: Akty mowy w języku nauczycieli, Katowice: Wyd. Uniwersytetu Śląskiego.

Filek, J., 1996: Ontologizacja odpowiedzialności, Kraków.

Fishman, J. A., (ed.), 1960: Readings in the sociology of language, Mouton.

Galasiński, D., 1992: Chwalenie się jako perswazyjny akt mowy, Kraków: PAN, Inst. Języka Polskiego.

Grabias, S., 2003: Język w zachowaniach społecznych, Lublin: UMCS.

Grzegorczykowa, R., 1988: Władanie językiem a wiedza o świecie, w: Bartmiński, J. (red.), 1988.

Habermas,J., 1999: Teoria działania komunikacyjnego, T. I, Wyd. Naukowe: PWN.

Hauser M. C., Chomsky N., Fitch W. T., 2002: The faculty of language. What is it? Who has it? How did it evolve? "Science", 298. (za:) Kurcz, I., 2005.

Heinz, A., 1978: Dzieje językoznawstwa w zarysie, Warszawa. (za:) Wołos, M., 2002: Koncepcja „gry językowej” Wittgensteina w świetle badań wspótczesnego językoznawstwa, Kraków: Universitas.

Hymes, D. H., 1960: Ethnography of speaking, w: Fishman, I., (ed.), Readings in the sociology of language,(ss.99-138). Mouton.

Ingarden, R., 1989: Wyktady z etyki, Warszawa.

Jedynak, A, Walentynowicz, T. 2001: Edukacja filozoficzna $w$ gimnazjum. Program nauczania dla gimnazjum. Warszawa.

Jonas, H., 1996: Zasada odpowiedzialności, Kraków.

Kojs, W., 1987: Dziatanie jako kategoria dydaktyczna, Katowice: Uniwersytet Śląski.

Kupisiewicz, Cz., 1976: Podstawy dydaktyki ogólnej, Warszawa: PWN.

Kurcz, I., 2001: Psychologia języka i komunikacji, Warszawa: Wydawnictwo „Scholar”.

Kurcz, I., 2005: Teoria umysłu a kompetencja komunikacyjna, w: Sierocka, B., (red.), Aspekty kompetencji komunikacyjnej, Wrocław: Oficyna Wydawnicza ATUT.

Lachur, Cz., 2004: Zarys językoznawstwa ogólnego, Opole.

Levinas, E., 2002: Catość i nieskończoność. Esej o zewnętrzności, Warszawa: Wyd. Naukowe PWN.

Majewska, M., 2005: Akty deprecjonujace siebie i innych. Studium pragmalingwistyczne, Kraków: Universitas.

Mrózka, R., 2000: Język w przestrzeni edukacyjnej, Katowice Wyd., Uniwersytetu Śląskiego.

Muszyński, Z., 1988: Problem wiedzy pozajęzykowej w badaniach lingwistycznych, w: Bartmiński, J. (red.), 1988.

Nęcki,Z., 2000: Komunikacja międzyludzka, Kraków: ANTYKWA.

Okoń, W.,1970: Zarys dydaktyki ogólnej, Warszawa.

Olbrycht K. (red.), 1999: Edukacja aksjologiczna. T. IV Wybrane problemy przekazu wartości, Katowice.

Puzynina, J. 1997: Stowo - wartość - kultura, Lublin: KUL.

Retter, H., 2005: Komunikacja codzienna w pedagogice, Gdańsk.

Searle, J., 1987: Czynności mowy, Warszawa.

Śnieżyński, M., 2005: Sztuka dialogu. Teoretyczne założenia a szkolna rzeczywistość, Kraków: Wyd. Naukowe Akademii Pedagogicznej.

Tchorzewski, A., M., 1998: Wielopłaszczyznowa odpowiedzialność nauczyciela, w: Odpowiedzialność jako wartość i problem edukacyjny. Bydgoszcz: Wydaw. „WERS”.

Wawrzyniak, J., 2002: Miedzy Platonem a prawdą: status etyki w kształceniu akademickim - cele, formy, metody, w: Piotrowska, Wiśniewski J. (red.), Dydaktyka filozofii. Doświadczenia - dylematy - osiqgnięcia, Poznań: Wyd., Fundacji HUMANIORA. 